\title{
PENGARUH UMUR INDUK IKAN CUPANG (Betta splenden Regan) DAN JENIS PAKAN TERHADAP FEKUNDITAS DAN PRODUKSI LARVANYA
}

\begin{abstract}
Darti Satyani
ABSTRAK

Pengaruh umur induk ikan cupang dan jenis pakan terhadap fekunditas dan produksi larva diteliti dalam satu kali pemijahan. Penelitian ini bertujuan untuk mengetahui umur produktif induk ikan cupang dan jenis pakan yang paling baik untuk produksi telur dan larvanya. Ikan uji sebanyak 90 ekor ikan cupang jantan dan 90 ekor betina umur $3 ; 3,5$; dan 4 bulan dengan ukuran panjang antara $3,6--4,5 \mathrm{~cm}$ dipelihara dalam 18 buah baskom. Perlakuan dilakukan dengan 3 jenis pakan yaitu kutu air (Daphnia sp.), cacing sutera (Tubifex sp.), dan jentik nyamuk. Pemijahan dilakukan dengan memasangkan ikan jantan dan betina sesuai perlakuan setelah pemeliharaan selama 15 hari, dalam 45 buah bak plastik. Rancangan percobaan adalah Rancangan Acak Lengkap pola faktorial $(2 \times 3 \times 5)$ dengan 2 faktor yaitu umur dan pakan. Faktor pertama adalah umur dengan 3 taraf dan faktor kedua adalah pakan dengan 3 taraf pula. Ulangan dilakukan 5 kali. Jumlah telur dan larva yang dihasilkan tiap pasangan induk terlihat lebih banyak seiring dengan naiknya umur ikan. Pakan kutu air memberikan hasil yang terbaik, sementara jentik nyamuk merupakan pakan yang hasil telur dan larvanya paling sedikit $(P<0,05)$. Pertumbuhan ikan jantan ternyata lebih cepat daripada ikan betina, sementara itu untuk petumbuhan ini pakan cacing merupakan pakan yang terbaik dengan laju pertambahan panjang badan paling cepat.
\end{abstract}

\section{ABSTRACT: Effect of age of fighting fish (Betta splenden Regan) and different types on its feed to fecundity and larval production. By: Darti Satyani}

Effect of age of fighting fish broodstocks and different types of feed on its fecundity and larval production in one spawning time was studied. The aim of this research was to know the productive age of the fighting fish broodstocks and the best feed for their eggs and larval production. Ninthly males and 90 females of 3, 3.5, and 4-month old with total length ranged between $3.6-4.0 \mathrm{~cm}$ size were reared in 18 buckets. Fish were treated with three types 15 day of feed i.e. water fleas (Daphnia sp.), Tubifex sp. worm and mosquito larvae. The broodstocks were spawned individually based on the treatment after 15-day rearing. Randomized Complete Factorial Design $(2 \times 3$ $x 5)$ was used in this experiment. The first factor was age in 3 levels and the second one was feed types in 3 levels. Five replications were applied. Egg and larval production every of broodstock increased as fish age increased. Broodstocks were fed with water fleas indicated the highest fecundity and larval production, while the effect of feeding mosquito larvae was the lowest $(P<0.05)$. The male fish grew faster compared to the female, and Tubifex $s p$. worm was the best food for growth stimulation.

KEYWORDS: $\quad$ fighting fish, age, feed, fecundity, larvae

\section{PENDAHULUAN}

Ikan cupang (Betta splenden Regan) merupakan ikan hias yang amat populer. Perdagangan ikan ini tidak terbatas hanya di pasar lokal tetapi juga diekspor ke mancanegara dalam jumlah cukup besar. Ikan ini terkenal dengan nama fighting fish karena jantannya amat senang berkelahi sehingga sering digunakan sebagai ikan aduan.

Ukuran ikan cupang relatif kecil (maksimal 6,5 cm) sehingga untuk memijahkannya tidak diperlukan tempat yang luas. Ukuran panjang ikan untuk mulai menjadi induk adalah sekitar $3,5 \mathrm{~cm}$ untuk betina dan 4 $\mathrm{cm}$ untuk jantan dengan umur sekitar 3--4 bulan, dan jumlah telur antara 500-700 butir (Sterba, 1978; Lee, 1986). Umumnya petani memijahkannya pada umur 4,5--6 bulan (Lesmana \& Dermawan, 2001).

Kematangan gonad dan keberhasilan pemijahan berhubungan dengan ukuran dan umur ikan. Billard (1992) mengatakan bahwa semakin besar ukuran ikan jumlah telurnya akan semakin banyak, ukuran telurnya juga relatif lebih besar, demikian pula kualitasnya semakin baik. 
Dalam pengelolaan induk selain ukuran dan umur, kualitas pakan juga amat berpengaruh terhadap kuantitas dan kualitas telur (Bromage \& Robert, 1995). Menurut Reay (1984), protein yang cukup merupakan kondisi nutrisi yang sangat menentukan, tidak hanya kualitas telur dan kehidupan larva tetapi juga keberhasilan pemijahan. Demikian pula lemak, vitamin $\mathrm{C}$ dan E, maupun karotenoid merupakan makro dan mikronutrisi yang berpengaruh cukup besar terhadap kualitas dan kuantitas telur (Bromage \& Robert, 1995).

Sifat ikan cupang adalah karnivora yang memakan hampir semua binatang kecil yang ada dalam air (Sanford, 1995). Ikan ini susah diberi pakan buatan sehingga menyebabkan kesukaran bagi para pembudi daya untuk memberikan nutrisi tambahan melalui pakannya. Jenis-jenis pakan hidup yang amat disukai oleh ikan air tawar termasuk ikan cupang adalah cacing sutera (Tubifex sp.), kutu air (Daphnia sp., Moina sp.), dan larva atau jentik nyamuk. Ketiga jenis pakan ini mempunyai kandungan nutrisi yang cukup baik (Chumaidi et al., 1990; Zonneveld et al., 1991).

Penelitian ini bertujuan untuk mengetahui pengaruh umur ikan cupang dan jenis pakan yang paling baik terhadap pemijahan, produksi telur, dan jumlah larvanya

\section{BAHAN DAN METODE}

Induk-induk ikan cupang yang digunakan dalam penelitian berumur $3 ; 3,5$; dan 4 bulan yang dipilih dan dibeli dari petani dengan ukuran $3,6--4,5 \mathrm{~cm}$. Jumlah ikan yang digunakan adalah sebanyak 90 ekor jantan dan 90 ekor betina dipelihara dalam 18 buah bak baskom volume $15 \mathrm{~L}$. Masing-masing baskom berisi 10 ekor induk yang dipisahkan antara jantan dan betina ( 9 baskom jantan dan 9 baskom betina). Perlakuan ada dua macam yaitu umur dan pakan. Perlakuan pakan adalah kutu air (Daphnia sp.), cacing sutera (Tubifex sp.), dan jentik nyamuk. Rancangan percobaan adalah Rancangan Acak Lengkap pola faktorial dengan 2 faktor perlakuan yaitu umur dan pakan masing-masing 3 taraf dengan ulangan 5 kali.

Pemberian pakan dilakukan ad libitum dua kali sehari. Tanaman air sebagai tempat persembunyian adalah enceng gondok (Eichornia crassipes) dan sedikit ganggang (Hydrilla sp.). Pemeliharaan dilakukan selama 15 hari.

Pemijahan dilakukan dengan memasangkan secara acak induk jantan dan betina sesuai perlakuan di dalam 45 buah baskom kecil ( $2 \mathrm{~L}$ ) yang sudah diberi lembaran daun enceng gondok. Fekunditas atau jumlah telur tiap induk dihitung terhadap semua pasangan pertama yang dipijahkan (45 pasang). Produksi larva dihitung dari penetasan telur pada pemijahan pasangan kedua atau 45 pasang lainnya.
$\mathrm{Hal}$ ini disebabkan telur yang sudah dihitung akan rusak dan tidak dapat ditetaskan lagi.

Penghitungan telur dan larva dilakukan langsung pada semua telur dan larva dengan handtally counter, hasil tiap pemijahan. Analisis data dengan uji ANOVA $(P<0,05)$.

\section{HASIL DAN BAHASAN}

Pemijahan yang dilakukan setelah 15 hari induk dipelihara dan diperlakukan, menghasilkan jumlah telur dan larva dari tiap pasangan seperti tertera pada Tabel 1. Jumlah telur terlihat lebih banyak dengan bertambahnya umur induk. Induk-induk ikan cupang yang jumlah telurnya paling sedikit adalah yang berumur 3 bulan, dan induk yang berumur 4 bulan jumlah telurnya yang terbanyak.

Menurut Lam (1983), induk betina yang baru mulai bertelur umumnya fekunditasnya masih sedikit, sedangkan yang jantan kualitas spermanya juga masih belum baik. Dengan demikian hasil pemijahan induk yang masih muda juga belum baik sehingga produksi larvanya umumnya juga masih sedikit. Hal ini terlihat pula pada produksi larva ikan cupang yang masih sedikit pada umur 3 bulan dan terlihat nyata paling tinggi pada umur 4 bulan.

Induk ikan yang baru pertama kali bertelur memiliki variasi jumlah telur dan larva antar individu yang kisarannya masih lebar (Lam, 1983). Hal ini pun dapat dilihat dari induk ikan cupang berumur 3 bulan di mana nilai kisaran fekunditas maupun produksi larvanya pada setiap pasangan induk paling lebar (Gambar 1.). Pada induk ikan umur 4 bulan nilai kisaran jumlah telur yang diproduksi antar induk ikan tidak terlalu besar. Oleh sebab itu memijahkan ikan cupang sangat dianjurkan untuk menggunakan induk yang sudah berumur 4 bulan agar telur yang dihasilkan dari tiap pasangan sudah cukup baik dan stabil

Perkembangan sel telur dalam gonad ikan betina disebut oogonesis dan pada jantan disebut spermatogenesis. Menurut Billard (1986), oogenesis melalu tiga tahapan yaitu previtellogenesis, vitellogenesis, dan maturasi.

Previtellogenesis atau perkembangan primer yaitu mulai terdeferensiasinya ovarium, terjadi pada ikan kecil sampai dewasa. Calon atau bakal oosit yang disebut oogonium akan bertumbuh kembang menjadi oosit muda pada saat ini, namun belum terjadi akumulasi material kuning telur.

Tahap vitellogenesis dan kematangan yaitu perkembangan sel telur menjadi besar, berisi kuning telur dan siap diovulasikan terjadi pada ikan dewasa. Dengan demikian oosit muda akan selalu ada dan siap pada ikan dewasa, sehingga proses pematangan 
Tabel 1. Rata-rata fekunditas atau jumlah telur dan larva tiap ekor induk ikan cupang berdasarkan umur dan jenis pakan $(N=45)(P<0,05)$

Table 1. Average fecundity (numbers of egg) and larvae of each fighting fish broodstock based on age and type of feed given $(N=45)(P<0.05)$

\begin{tabular}{|c|c|c|c|c|c|}
\hline & $\begin{array}{l}\text { Umur/Pakan } \\
\text { Age/Feed }\end{array}$ & $\begin{array}{l}\text { Kutu air } \\
\text { Water fleas }\end{array}$ & $\begin{array}{l}\text { Cacing sutera } \\
\text { Tubifex worm }\end{array}$ & $\begin{array}{l}\text { Jentik nyamuk } \\
\text { Mosquito larvae }\end{array}$ & $\begin{array}{l}\text { Rata-rata } \\
\text { Average }\end{array}$ \\
\hline \multirow[t]{4}{*}{$\begin{array}{l}\text { Fekunditas } \\
\text { Fecundity }\end{array}$} & $\begin{array}{l}3 \text { bulan } \\
3 \text { months }\end{array}$ & 751.0 & 750.8 & $645.4^{*}$ & $715.7^{b}$ \\
\hline & $\begin{array}{l}3,5 \text { bulan } \\
3.5 \text { months }\end{array}$ & 760.8 & 764.2 & 661 & $728.7^{b}$ \\
\hline & $\begin{array}{l}4 \text { bulan } \\
4 \text { months }\end{array}$ & $785.0^{* *}$ & 779.8 & 706.8 & $757.2^{a}$ \\
\hline & $\begin{array}{l}\text { Rata-rata } \\
\text { Average }\end{array}$ & $765.6^{c}$ & $764.9^{c}$ & $671.1^{d}$ & \\
\hline \multirow[t]{4}{*}{$\begin{array}{l}\text { Larva } \\
\text { Larvae }\end{array}$} & $\begin{array}{l}3 \text { bulan } \\
3 \text { months }\end{array}$ & 745.8 & 745.2 & 647.6 & $712.9^{b}$ \\
\hline & $\begin{array}{l}3,5 \text { bulan } \\
3.5 \text { months }\end{array}$ & 761.4 & 747.0 & 654.0 & $720.8^{b}$ \\
\hline & $\begin{array}{l}4 \text { bulan } \\
4 \text { months }\end{array}$ & $796.4^{* *}$ & 773.2 & 702.0 & $757.5^{\mathrm{a}}$ \\
\hline & $\begin{array}{l}\text { Rataan } \\
\text { Average }\end{array}$ & $767.9^{c}$ & $755.1^{c}$ & $668.1^{d}$ & \\
\hline
\end{tabular}

Keterangan: Angka dalam baris dan kolom yang diikuti huruf sama tidak berbeda nyata $(P<0,05)$

** Interaksi kuat $(P<0,01)$

* Interaksi lemah $(P<0,05)$

Note: Values in rows and columns followed by the same superscripts are not significantly different $(P<0.05)$

** Strong interaction $(P<0.01)$

* Weak interaction $(P<0.05)$

gonad pada ikan dewasa atau induk sebenarnya terjadi mulai dari oosit muda dan bukan dari calon telur. Siklus ini pada ikan-ikan tertentu terutama pada spesies ikan berukuran kecil dan berumur pendek seperti ikan cupang dapat amat pendek yaitu 2 sampai 3 minggu saja. Sementara pada spesies ikanikan berukuran besar dapat memakan waktu berbulanbulan bahkan satu tahun.

Tidak semua oosit muda dapat menjadi oosit matang dan siap ovulasi, tetapi beberapa oosit mungkin akan mengalami kegagalan yang disebabkan oleh pengaruh dari luar yaitu lingkungan atau pakan yang kurang baik. Oosit yang gagal berkembang ini menurut Billard (1992), akan menjadi oosit periode istirahat yang dapat berkembang pada periode selanjutnya.

Perkembangan sperma dalam testis juga mirip dengan perkembangan sel telur tetapi prosesnya lebih sederhana dan lebih cepat, sehingga sperma ikan jantan umumnya akan siap setiap saat. Produksi sperma ini juga dipengaruhi oleh lingkungan dan pakan.
Pada penelitian ikan cupang ini kisaran produksi telur dan larva yang lebar yaitu pada umur 3 bulan (induk mulai bertelur) amat mungkin disebabkan pertumbuhan oosit muda banyak yang masih belum sempurna. Pada induk dengan umur yang lebih tua yaitu 4 bulan, pertumbuhan oosit muda sudah maksimal sehingga variasinya lebih kecil dengan produksi yang lebih stabil.

Pengaruh pakan terhadap fekunditas dan produksi larva induk-induk cupang cukup nyata. Induk yang diberi pakan dari jenis daphnia dan cacing sutera memberikan hasil fekunditas yang nyata lebih tinggi $(P<0,05)$ dibanding induk yang diberi pakan jentik nyamuk. Produksi larva dari induk-induk cupang dengan perlakuan daphnia dan cacing juga memperlihatkan kecenderungan yang sama yaitu lebih tinggi $(P<0,05)$ dari produksi larva ikan dengan pakan jentik nyamuk.

Produksi larva amat erat kaitannya dengan jumlah dan kualitas telur. Khusus ikan cupang ini karena penetasannya hanya dapat terjadi apabila masih di 


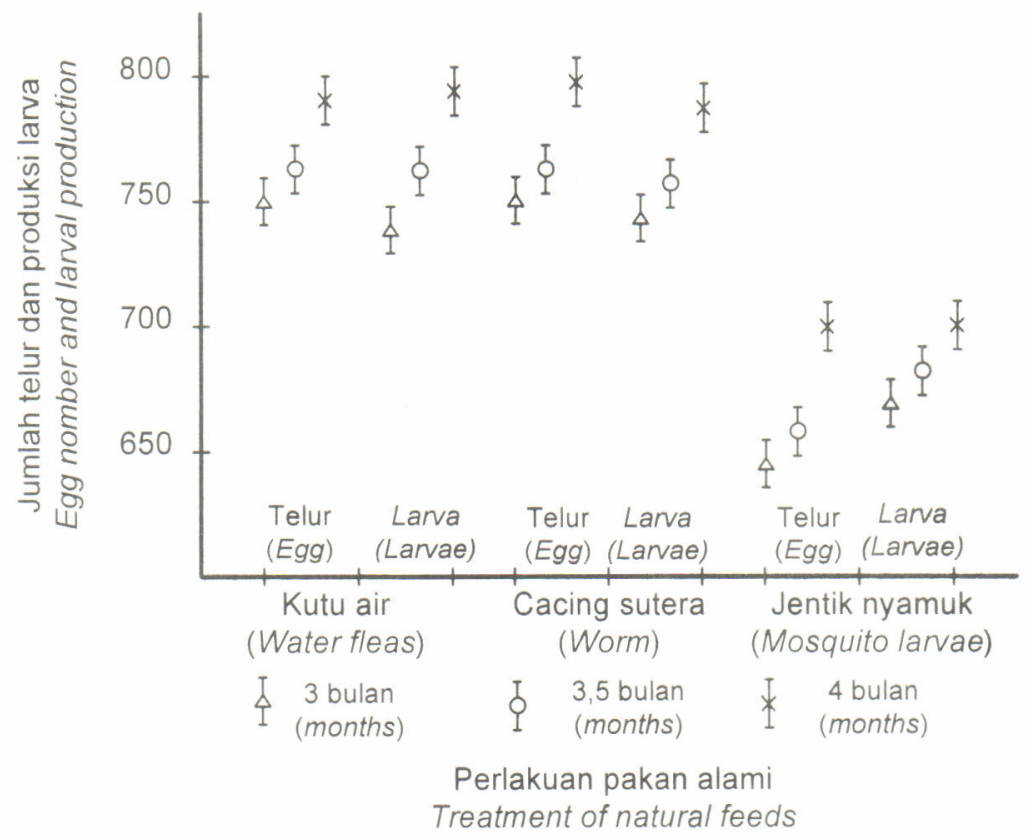

Gambar 1. Kisaran rata-rata jumlah telur dan produksi larva induk ikan cupang pada masing-masing perlakuan Figure 1. Average egg number and larval production of fighting fish broodstocks at each treatment

sarang busa dan harus ditunggui oleh induk jantannya sehingga telur yang tidak menetas tidak akan dapat dihitung. Hal ini karena telur yang tidak menetas umumnya menjadi hilang atau dimakan oleh induknya. Dengan demikian maka daya tetas telur adalah jumlah telur yang menetas dibandingkan dengan produksi telur total tidak dapat dihitung

Kandungan protein, lemak, maupun vitamin menurut Briomage \& Robert (1995), selain mempengaruhi pertumbuhan juga akan berpengaruh besar terhadap kapasitas reproduksi ikan antara lain jumlah dan kualitas telur serta produksi larva. Arifin \& Asyari (1994) menganjurkan kadar protein untuk indukinduk patin adalah sekitar $40 \%--47 \%$ agar telur yang dihasilkan baik jumlah maupun kualitasnya dapat optimal. Tacon (1987) dalam Djajasewaka et al. (1994) merekomendasikan untuk ikan-ikan karnivora pakan dengan kandungan protein untuk induk $47 \%$ adalah minimal yang harus diberikan. Djajasewaka et al. (1998) pada penelitiannya menggunakan pakan dengan kandungan protein $50 \%$ yang diberikan pada induk betutu menghasilkan jumlah telur yang paling tinggi dibandingkan dengan pakan berkandungan protein lebih rendah. Daphnia, cacing sutera, maupun jentik nyamuk yang memiliki kandungan protein berturut-turut sebesar $60,12 \% ; 53,77 \%$; dan $67,80 \%$. Protein ini lebih dari mencukupi kebutuhan dalam menunjang produksi telur dengan kualitas dan kuantitas yang baik. Tetapi dari data yang diperoleh maka daphnia dan cacing adalah nyata lebih tinggi $(P<0,05)$ hasilnya, dengan daphnia yang paling tinggi.
Dari analisis nutrisi yang diperoleh kandungan protein dari daphnia ini memang lebih tinggi dari cacing rambut (Tabel 2)

Walaupun jentik nyamuk kandungan proteinnya adalah paling tinggi, hasil telur dan larvanya ternyata adalah paling rendah. Kemungkinan adanya kandungan lemak yang terlalu tinggi diduga mempengaruhi hasil ini. Menurut Dutta (1973), pemberian pakan pada ikan hias dengan kandungan lemak yang tinggi akan membuat kualitas telur menjadi jelek. Kandungan lemak dalam pakan dianjurkan sekitar $8 \%--10 \%$ saja. Hal ini disebabkan lemak akan tertimbun dalam telur dan mengurangi jumlah yolk atau kuning telur sebagai parameter turunnya kualitas telur atau kemungkinan juga dari adanya kandungan serat yang tinggi sehingga mempengaruhi daya serap nutrisi. Belum diperoleh keterangan mengenai hal ini karena tidak dilakukan penelitian sampai ke sana. Kandungan serat kasar yang tinggi apalagi yang keras seperti pada jentik nyamuk menurut De Silva \& Anderson (1995), sangat mempengaruhi kecernaan pakan. Penurunan penyerapan gizi dapat disebabkan oleh jenis pakan seperti ini. Oleh karena itu walaupun pakan jentik nyamuk memiliki kandungan gizi paling tinggi baik dalam protein maupun lemak, induk cupang yang diberi pakan jentik menunjukkan produksi telur dan larva yang terlihat paling rendah $(P<0,05)$

Faktor lain yang mempengaruhi fekunditas dan produksi larva adalah adanya mikronutrien yaitu vitamin dan karoten (Bromage \& Robert, 1995). 
Tabel 2. Analisis kandungan gizi dari pakan perlakuan induk-induk ikan cupang (\%)

Table 2. Nutrition analysis of feeds given at fighting fish broodstock treatment(\%)

\begin{tabular}{lrrrrr}
\hline & $\begin{array}{c}\text { Kandungan air } \\
\text { Water content }\end{array}$ & $\begin{array}{c}\text { Protein } \\
\text { Protein }\end{array}$ & $\begin{array}{c}\text { Lemak } \\
\text { Fat }\end{array}$ & $\begin{array}{c}\text { Serat kasar } \\
\text { Fiber }\end{array}$ & $\begin{array}{l}\text { Abu } \\
\text { Ash }\end{array}$ \\
\hline Daphnia sp. & 90.78 & 60.12 & 8.10 & 2.58 & 4.76 \\
Cacing sutera (Tubifex worm) & 86.70 & 53.77 & 13.30 & 2.04 & 3.64 \\
Jentik nyamuk (Mosquito lana) & 81.80 & 67.80 & 14.60 & 12.20 & - \\
\hline
\end{tabular}

Kandungan vitamin seperti vitamin $A, C, D$, dan E pada pakan alami baik kutu air seperti daphnia, cacing sutera, maupun larva nyamuk menurut Zonneveld (1991) adalah cukup baik. Tetapi lain halnya dengan karoten di mana pada kutu air kandungannya menurut Latscha (1990) dan Simpson et al. (1981) cukup tinggi. Sementara cacing sutera dan jentik nyamuk merupakan pakan yang miskin karoten. Karoten juga diketahui sebagai bahan atau nutrisi yang secara fisiologis berperan besar dalam sistem endokrin yang berkenaan dengan perkembangan gonad, kematangan gonad, fertilisasi, dan pertumbuhan ikan (Meyers, 1977 \& Goodwin, 1984 dalam Latscha, 1990).

Interaksi yang kuat dalam fekunditas dan produksi larva secara nyata terjadi pada induk cupang umur 4 bulan dengan pakan daphnia (Tabel 1). Induk umur 4 bulan merupakan yang paling baik dalam merespon jenis pakan ini. Sementara itu induk ikan umur 3 bulan dengan pakan jenis jentik nyamuk, respon paling rendah terjadi hanya dalam fekunditas. Dalam hal produksi larva, induk 3 bulan dengan ketiga jenis pakan ini responnya tidak berbeda nyata $(P<0,05)$.

Pakan jentik nyamuk ini sebenarnya oleh para petani sangat dipercaya sebagai pakan yang cukup baik malah amat baik untuk ikan cupang aduan. Tetapi data yang diperoleh untuk produksi telur, larva, dan pertumbuhan menunjukkan hasil yang paling rendah. Selain itu tentunya dari segi kesehatan dan sanitasi di mana nyamuk seharusnya tidak boleh ada dalam lingkungan terutama pekarangan, maka produksi jentik nyamuk jelas akan mengundang penyakit. Walaupun demikian kajian lebih lanjut mengenai pengaruhnya terhadap agresivitas untuk cupang adu mungkin pula layak untuk dipelajari atau diteliti.

\section{KESIMPULAN DAN SARAN}

1. Umur sangat mempengaruhi jumlah telur dan larva induk ikan cupang. Induk umur 4 bulan hasil produksinya merupakan yang tertinggi.

2. Pakan kutu air yaitu Daphnia sp. merupakan pakan yang paling baik untuk menunjang produksi telur dan larva.

\section{DAFTAR PUSTAKA}

Arifin dan Asyari.1994. Pengaruh pakan terhadap pematangan calon induk patin (Pangasius pangasius). Prosiding Seminar Hasil Penelitian Perikanan Air Tawar 1992/1993 Balitkanwar, Sukamandi. p. 212--214.

Billard, R. 1986. The Reproductive Cycles of Male and Female Brown-trout (Salmo truta farto): A Quantitative Study. INRA Station de Physiologic animale. 12 pp.

Billard, R. 1992. Reproduction in rainbow trout, dynamic of gametogenesis, biology and preservation of gametes. Aquaculture, 100: 263--298.

Bromage, N.R. and R.J. Robert. 1995. Broodstock Management and Egg and Larval Quality. Blackwell Science Ltd. Cambridge USA, 1--76.

Chumaidi, S. Ilyas, Yunus, Sahlan, R. Utami, A. Priyadi, P.T. Imanto, S.T. Hartati, D. Bastiawan, Z. Jangkaru, dan R. Arifudin. 1990. Petunjuk Teknis Budidaya Pakan Alami. Puslitbangkan, Jakarta, 25 pp.

De Silva S.S. and T.A. Anderson. 1995. Fish Nutrition in Aquaculture. Chapman \& Hall. London-Madras, 128: 140.

Djajasewaka, H., M. Sulhi, dan Kusdiarti. 1994. Kebutuhan protein optimal dalam pakan induk ikan betutu (Oxyeleotris marmorata). Laporan Penelitian $1997 / 1998$ Balitkanwar Sukamandi, 6 pp.

Dutta, R. 1973. The Right Way to Keep Pet Fish. Paterfrons. Ellrot Right Waybooks, p. 25--27.

Forberg, K.G. 1982. Gonad maturation of female capelin (Mallotus villosus villosus). Proc. of the Intern. Symp. on Reprod. Physiol. of Fish. p. 197--200.

Hardjamulia, A. 1992. Teknologi pembenihan ikan jelawat (Leptobarbus hoeveni) secara terkontrol. Seri Pengembangan Hasil Penelitian Perikanan. Balitbang Pertanian. Jakarta. 20 pp.

Lam, T.J. 1989. Environmental influence on ganadal activity in fish. In. Fish Physiology. Academic PressNew Yorkk-Toronto. p. 65--68.

Latscha, T. 1990. Carotenoids Their Nature and Significance in Animal Feeds. F. Hoffman-La Roche Ltd. Basil Switzerland.

Lee, C.K. 1986. Goldfish and Tropical Fish.Tropical Press. SDN. BHD. Kualalumpur, p. 23--24.

Lesmana, D.S. dan I. Dermawan. 2001. Budidaya Ikan Hias Air Tawar Populer. Penebar Swadaya. Jakarta. p. 26--30. 
Lim, C. 1985. Fish Nutrition and Feed Technology Research in Indonesia. RICA and RIFF. p. 40--41.

Reay, P.J. 1984. Reproductive tactics: A non event in aquaculture. In. Fish Reproduction: Strategies and Tactics. Academic Press. London. $291 \mathrm{pp}$.

Sanford, G. 1995. An Illustration Encyclopedia of Aquarium Fish. Apple Press. London. 68 pp.

Simpson, K.C., L. Katayama, and C.O. Chichester. 1981. Carotenoid in Fish Feed. Academic Press. 345 pp.
Sterba, G. 1978. The Aquarist"s Encyclopedia. Blandford Press. Dorset. GDR. 285 pp.

Woynarowich, E. and L. Hovarth. 1980. The artificial propagation of warmwater finfish: A manual for extension. Fisheries Technical Papers, FAO. Rome, 201 $p p$.

Zonneveld, N.E.A., Huisman, dan J.H. Boon. 1991 Prinsip-Prinsip Budidaya Ikan. Gramedia Pustaka Utama. Jakarta 